\title{
Dynamics of Land Use and Land Cover Change Using Remote Sensing and GIS: A Case Study of Debre Tabor Town, South Gondar, Ethiopia
}

\author{
Afera Halefom, Asirat Teshome, Ermias Sisay, Imran Ahmad \\ Department of Hydraulic and Water Resources Engineering, Debre Tabor University, Debre Tabor, Ethiopia \\ Email: aferahalefom@gmail.com, tesheasirat@gmail.comermasisay@gmail.com,wonder_env@yahoo.com
}

How to cite this paper: Halefom, A., Teshome, A., Sisay, E. and Ahmad, I. (2018) Dynamics of Land Use and Land Cover Change Using Remote Sensing and GIS: A Case Study of Debre Tabor Town, South Gondar, Ethiopia. Journal of Geographic Information System, 10, 165-174. https://doi.org/10.4236/jgis.2018.102008

Received: January 24, 2018

Accepted: April 5, 2018

Published: April 8, 2018

Copyright $\odot 2018$ by authors and Scientific Research Publishing Inc. This work is licensed under the Creative Commons Attribution International License (CC BY 4.0).

http://creativecommons.org/licenses/by/4.0/

(c) (i) Open Access

\begin{abstract}
The importance of accurate and timely information describing the nature and extent of land resources and changes over time is increasing, especially in fast-growing urban areas. We have developed a methodology to detect changes in land cover using satellite images for the years 1997, 2002, 2012 and 2017. The categories of five-class classification in the study area were built up area, plantation, waterbody, agricultural land and pastureland. The maps showed that between 1997 and 2017, the amount of urban or developed land increased from $8.12 \%$ to $52.4 \%$ of the total area, while agriculture land, plantation, waterbody and pastureland decreased from the $91.88 \%$ to $47.6 \%$ from the entire study area. The results showed that the urban (highly built-up) area increased dramatically. Inversely, pastureland, agricultural land, waterbody, and plantation decreased obviously from the period of 1997 to 2017. The remote sensing and GIS technique used in this study proved to be efficient; the time was shortened for the analysis of the city extension; and it was discovered that it was a useful tool to evaluate the effects of urbanization on the basis of the satellite image of the given years. The results quantify land use, coverage change patterns in Debre Tabor Town and demonstrate the potential of remote sensing, and GIS tools provide an accurate and cost-effective means to track land cover changes along time that can be used as management decisions and guidelines.
\end{abstract}

\section{Keywords}

Debre Tabor, GIS, Remote Sensing, LULC

\section{Introduction}

The Earth's surface has undergone changes and modifications throughout its history and existence on different scales of space and time, some in short periods 
and others for many years; some reversible and others irreversible [1]. The magnitude, pace and the spatial extent of direct and indirect changes in the earth's surface in recent decade according to [2] are unprecedented [2]. They also postulate that land use and land cover change are the effectors and key outcomes of man-made changes in the Earth's surface. Moreover, when globally aggregated, both changes are so insidious that they significantly affect the essential aspects of Earth system functioning. Land cover refers to visible land use evidence that has both vegetative and non-vegetative characteristics, while land use can be defined as altering and managing the natural environment such as arable land, grassland, pastures and managed forests with their functional roles in the respective catchment areas [3]. Land cover is easy to spot in the area, as land use is usually deducted from land cover and both of them are closely related because they are used together in the mapping to avoid ambiguity of the study area [4].

Urban growth, especially the relocation of residential and commercial land to rural areas on the periphery of metropolitan areas, has long been considered a sign of regional economic power. However, their benefits are increasingly being offset by the impact of ecosystems, including the degradation of air and water quality and the loss of arable land and forests and the socio-economic impact of economic disparities and social fragmentation and infrastructure costs, and identify the outflow of urban growth with SWAT models [5] [6] [7]. Land changes, commonly referred to as urban expansion, coupled with the rapid expansion of sparsely populated suburbs in formerly rural areas and the creation of exurbs, urban or suburban areas buffered by underdeveloped countries, have implications for the key aspects of the Earth system. Land cover refers to visible evidence of land use that has both vegetative and non-vegetative characteristics, while land use can be defined as human land use, usually with a focus on land use [3]. The pattern of land use and land cover of a region is widely considered the result of natural and socioeconomic factors and their use by humans in time and space [8] [9]. Substantial data on the surface of the earth is required for effective monitoring and analysis of changes in land use/land cover. Previously, such information on land use and cover change was generated around the world primarily by conventional land recognition methods, which not only required a lot of time, cost and effort, but was also a little practical to monitor dynamic changes in shorter time periods [10] [11]. Recent advances in geographic information system (GIS) and remote sensing (RS) instruments and techniques enable researchers to effectively model urban growth. Satellite Remote Sensing images provide excellent data sources from which efficient information about land use and land cover can be efficiently extracted, analyzed and simulated. Satellite remote sensing, for example, as shown in the works of [12] [13] [14], has the potential to provide accurate and timely geodata describing changes in land use/land cover of agglomerations. Urban expansion has increased the exploitation of natural resources and changed the use of land and land cover patterns [15]. For example, they have linked regional economic vitality with urban growth or expansion, especially with the movement from private and commer- 
cial use of land to rural areas in the periphery of major cities. Substantial data on the surface of the earth is required for effective monitoring and analysis of changes in land use/land cover. So far, all over the world, such information on land use/cover change has been generated mainly by conventional methods of soil removal, which not only took a long time, were expensive and lengthy and required a lot of work, but also was a little practical to accommodate dynamic changes in land use to monitor for shorter periods of time [10]. Recent advances in geographic information system (GIS) and remote sensing (RS) instruments and techniques enable researchers to effectively model urban growth. Remote Sensing satellite images provide excellent data sources from which efficient information on land use and land cover can be efficiently extracted, analyzed and simulated. Satellite remote sensing, for example, as shown in the works of [12] [13] [14] has the potential of providing accurate and timely geospatial information that describe changes in land use/land cover of metropolitan areas.

Land use data are needed to analyze environmental processes and problems that need to be understood in order to improve or maintain living conditions and standards at the current level. The present study describes the various changes in the categories land use/land cover and study area. The present study was conducted to understand changes in land/soil utilization in Debre Tabor City, South Gondar, Ethiopia.

This area is known for its extensive urbanization process, which has led to chaotic growth in the city, worsened living conditions, and worsened the environmental scenario that has deleterious effects on human health. Therefore, it is necessary to determine the rate and trend of land use in order to design a rational land use policy. The aim of the study was a study/comparative analysis of the change in land use of the city of Debre Tabor with RS and GIS tools.

\section{Materials and Methods}

\subsection{Study Area Description}

The selected study area is found in the South Gonder Administrative Zone of Amhara National Regional State, North Central Ethiopia, about 100 kilometers southeast of Gondar and 50 kilometers east of Lake Tana. The surface area of Debre Tabor city is about $31.87 \mathrm{~km}^{2}$. The study area extends between $11.83^{\circ} \mathrm{N}$ to $11.87^{\circ} \mathrm{N}$ latitude and $37.98^{\circ} \mathrm{E}$ to $38.03^{\circ} \mathrm{E}$ longitude in Figure 1. Topographically, the city is characterized by undulating terrain with significant elevation variation. The southern and southwestern parts of the town are more of higher ground including Mount tabor.

The climate of Debre Tabor is based on its altitude which ranges between 2447 $\mathrm{m}$ and $2838 \mathrm{~m}$ is Dega. Climatically, the study area enjoys moderate temperate climatic conditions. The mean annual rainfall is $1553.7 \mathrm{~mm}$. The maximum rainfall occurs in July or August.

\subsection{Sources Data and Analysis Methods}

Source for land use and land cover dynamics was freely downloaded Landsat 


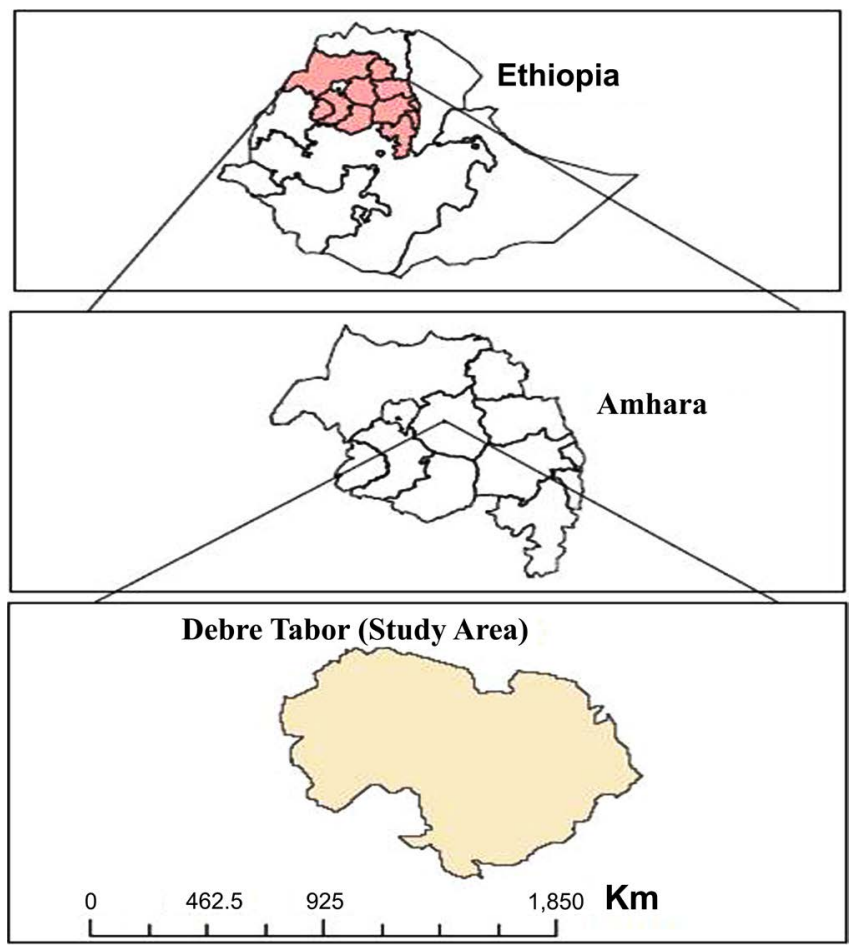

Figure 1. Location of study area of Debre Tabor town.

imagery from http://earthexplore.usgs.gov/. The detail of satellite data are presented in Table 1. The imagery was processed using ArcGIS10.3 and ERDAS IMAGE14 software. The various steps developed and used to analyse, quantify and interpret the map are presented in Figure 2. Area of interests (AOIs) were selected and collected as training areas for unsupervised classification of the pre-defined land cover types (LCTs). Pixels were clustered into the categories of Built-up area, Plantation, Water body, Agricultural land and Pasture land in Table 2. Variable numbers of AOIs were used to classify the images of the four dates (1997, 2002, 2012 and 2017) (Table 1).

\section{Change Detection Analysis}

Change detection analyses describes and quantify differences between images of the same scene at different times.

The classified images of the four dates can be used to calculate the area of different land cover and observe the changes that are taking place in the span of data. This analysis is very much helpful to identify various changes occurring in different classes of land use like increase in urban built-up area or decrease in vegetation and so on.

\section{Result and Discussion}

\subsection{Land Use Land Cover Changes Dynamics}

The change in land use/land cover in general and land cover in particular would have direct or indirect impacts on the extent of urban growth. The extension of 
Table 1. Satellite images used.

\begin{tabular}{ccccccc}
\hline s. no. & Image & Resolution $(\mathrm{m})$ & Sensor & Path & Row & Source \\
\hline 1. & Landsat 8 & $30 \times 30$ & TM & 169 & 52 & $\underline{\text { http://earthexplore.usgs.gov/ }}$ \\
2. & Landsat 7 & $30 \times 30$ & TM & 169 & 52 & $\underline{\text { http://earthexplore.usgs.gov/ }}$ \\
3. & Landsat 7 & $30 \times 30$ & TM & 169 & 52 & $\underline{\text { http://earthexplore.usgs.gov/ }}$ \\
4. & Landsat 7 & $30 \times 30$ & TM & 169 & 52 & http://earthexplore.usgs.gov/ \\
\hline
\end{tabular}

Table 2. Details of land cover categories.

\begin{tabular}{|c|c|}
\hline Land cover types & Description \\
\hline Built-up area & $\begin{array}{l}\text { This category comprises all the manmade infrastructures like buildings, } \\
\text { roads and concretized area }\end{array}$ \\
\hline Plantation & $\begin{array}{l}\text { This category comprised of planted junipers, eucalyptus trees, Acacia } \\
\text { and natural forest or areas covered by trees planted around homesteads } \\
\text { and some public institution areas. }\end{array}$ \\
\hline Water body & Manmade wells and ponds \\
\hline Agricultural land & Agricultural fields \\
\hline Pasture land & $\begin{array}{l}\text { Land under permanent pasture and grassland and it is owned either } \\
\text { grazing areas or also those owned by various institutions. This includes } \\
\text { grasslands, playground with grass covered, and garden }\end{array}$ \\
\hline
\end{tabular}

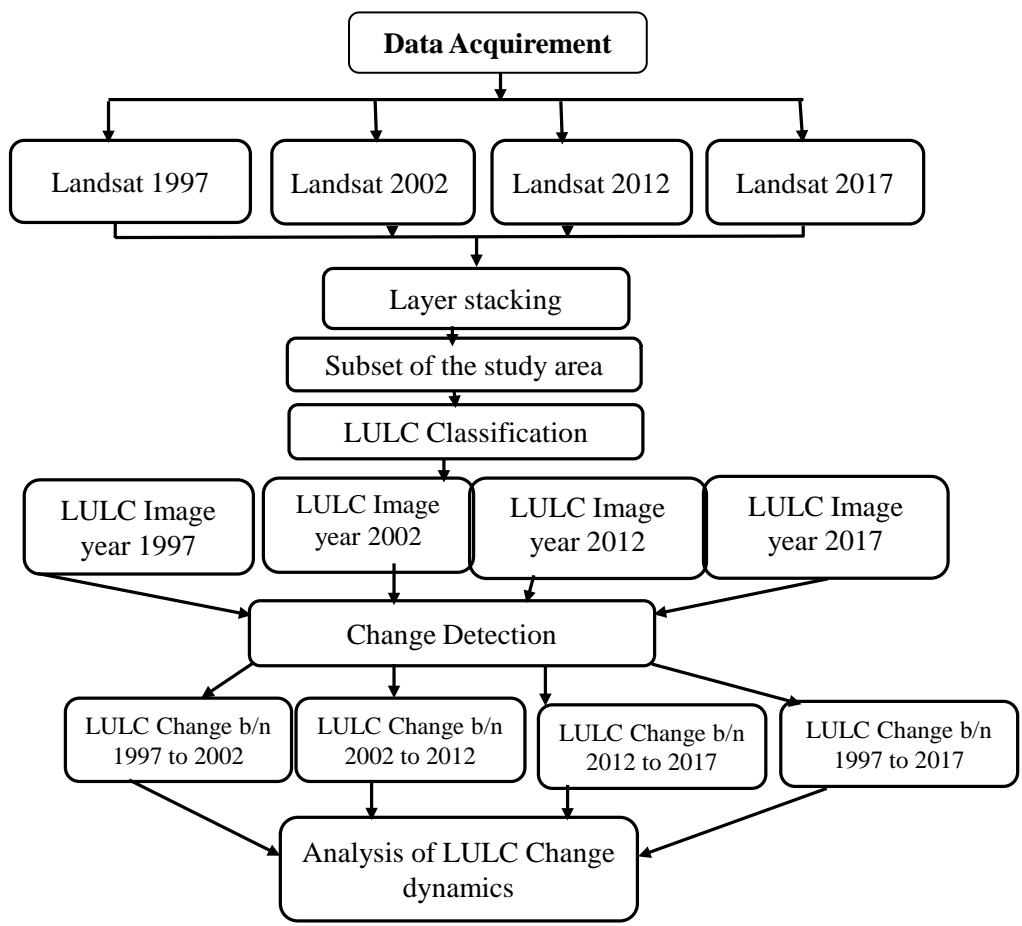

Figure 2. Illustrate the methodology adopted for land use classification and land use change detection.

the area of land use/changes in land cover from 1997 to 2017 for the city of Debre Tabor presented in Table 3 and Figure 3(a) \& Figure 3(b) and Figure 4.

The land use/land cover statistics were calculated and summarized to detect 
Table 3. Area coverage of each LCT from 1997-2017.

\begin{tabular}{ccccccccc}
\hline \multirow{2}{*}{ LCT } & \multicolumn{2}{c}{1997} & \multicolumn{2}{c}{2002} & \multicolumn{2}{c}{2012} & \multicolumn{2}{c}{2017} \\
\cline { 2 - 8 } & $\mathbf{A ~ ( \mathrm { km } ^ { 2 } )}$ & $\mathbf{A ~ ( \% )}$ & $\mathbf{A ~ ( \mathrm { km } ^ { 2 } )}$ & $\mathbf{A ~ ( \% )}$ & $\mathbf{A ~ ( \mathrm { km } ^ { 2 } )}$ & $\mathbf{A}(\%)$ & $\mathbf{A ~ ( \mathrm { km } ^ { 2 } )}$ & $\mathbf{A}(\%)$ \\
\hline Built-up area & 2.60 & 8.16 & 5.86 & 18.39 & 7.94 & 24.90 & 16.7032 & 52.41 \\
Plantation & 8.40 & 26.36 & 2.62 & 8.22 & 4.08 & 12.80 & 4.7892 & 15.03 \\
water body & 0.00 & 0.00 & 0.48 & 1.51 & 0.40 & 1.26 & 0 & 0.00 \\
$\begin{array}{c}\text { Agricultural } \\
\text { land }\end{array}$ & 15.60 & 48.95 & 19.88 & 62.38 & 18.22 & 57.18 & 9.5993 & 30.12 \\
$\begin{array}{c}\text { Pasture land } \\
\text { Total }\end{array}$ & 5.27 & 16.53 & 3.03 & 9.51 & 1.24 & 3.89 & 0.78 & 2.45 \\
\hline
\end{tabular}
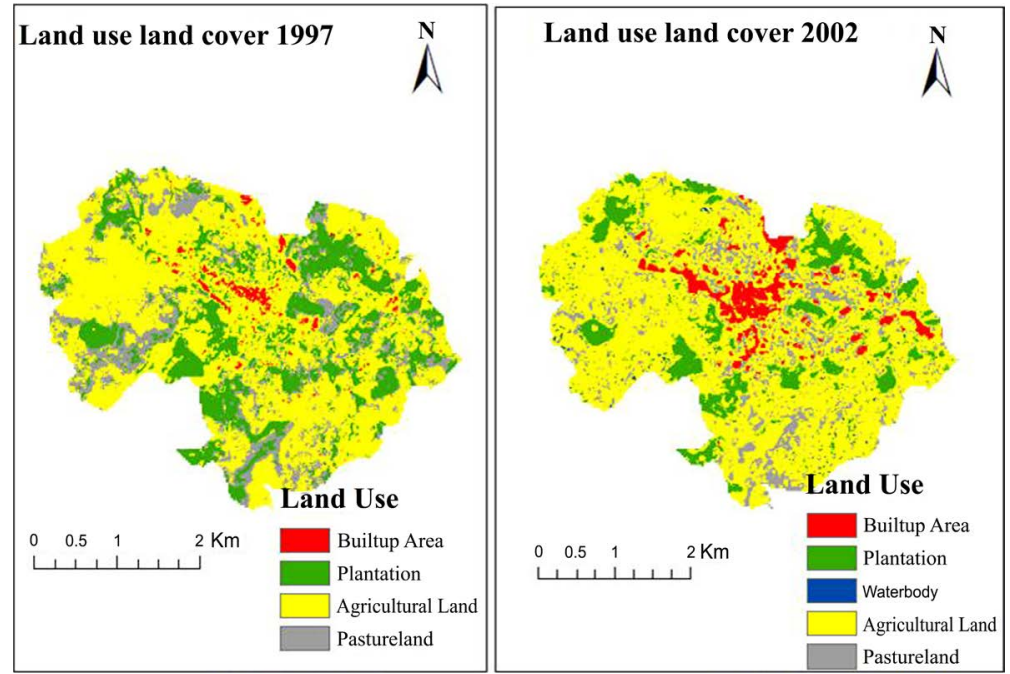

(a)

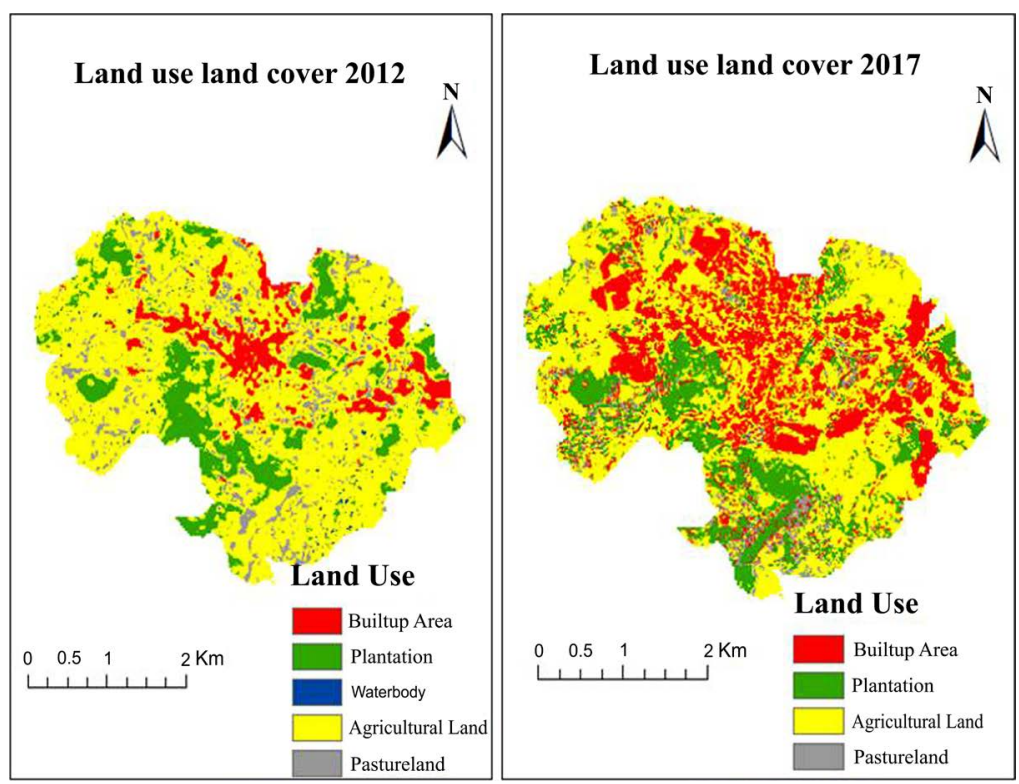

(b)

Figure 3. (a) Land covers maps of Debre Tabor town in 1997 and 2002; (b) Land covers maps of Debre Tabor town in 2012 and 2017. 
the nature of the main changes that occurred between 1997 and 2017 shown in Table 4. There was a significant increase in the percentage of built area from 1997 to 2017. The result indicates that the agricultural land was lost its extension of coverage area from 1997 to 2017. This reveals agricultural land for residential purpose. The rate of increase of the urbanized area was very high in 20 years. In 2017 , the constructed area was approximately $16.7 \mathrm{~km}^{2}$. The construction covers around $52.4 \%$ of the total study area.

Almost all the components of land cover have changed (gains or losses) according to the time in the last 20 years. As indicated in Figure 5, all land cover

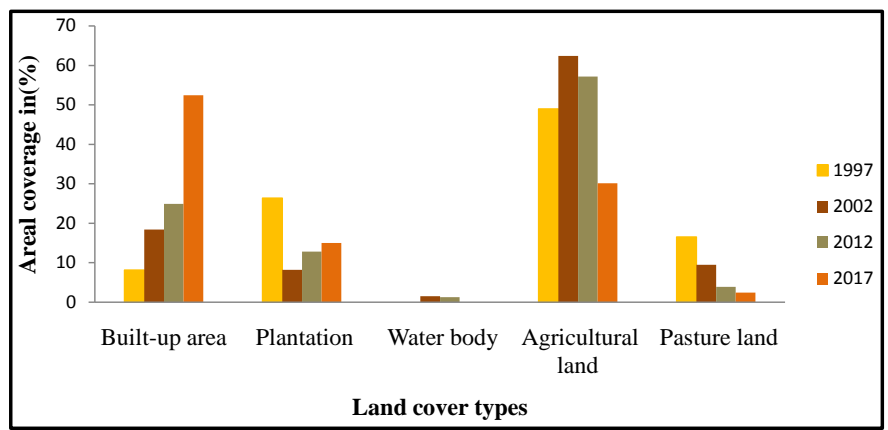

Figure 4. Status on land covers classification in 1997, 2002, 2012 and 2017.

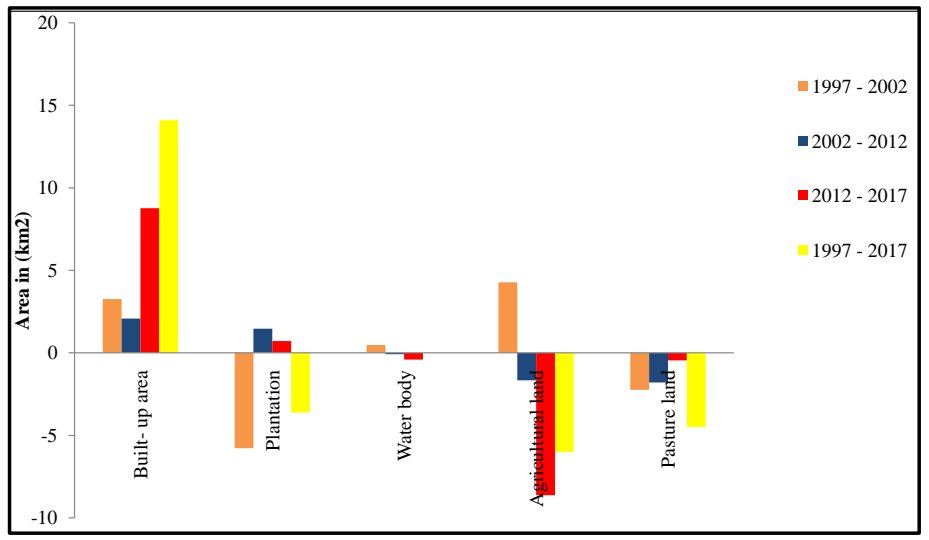

Figure 5. Area increase and decrease in LULC between 1997 and 2017.

Table 4. Summary statistics of land use/land cover from 1997 to 2017.

\begin{tabular}{ccccccccc}
\hline \multirow{2}{*}{ LCT } & 1997 & 2002 & 2012 & 2017 & $1997-2002$ & $2002-2012$ & $2012-2017$ & $1997-2017$ \\
\cline { 2 - 9 } & $\mathrm{A}\left(\mathrm{km}^{2}\right)$ & $\mathrm{A}\left(\mathrm{km}^{2}\right)$ & $\mathrm{A}\left(\mathrm{km}^{2}\right)$ & $\mathrm{A}\left(\mathrm{km}^{2}\right)$ & $\mathrm{A}\left(\mathrm{km}^{2}\right)$ & $\mathrm{A}\left(\mathrm{km}^{2}\right)$ & $\mathrm{A}\left(\mathrm{km}^{2}\right)$ & $\mathrm{A}\left(\mathrm{km}^{2}\right)$ \\
\hline Built up area & 2.60 & 5.86 & 7.94 & 16.70 & 3.26 & 2.08 & 8.77 & 14.10 \\
Plantation & 8.40 & 2.62 & 4.08 & 4.79 & -5.78 & 1.46 & 0.71 & -3.61 \\
Water body & 0.00 & 0.48 & 0.40 & 0.00 & 0.48 & -0.08 & -0.40 & 0.00 \\
$\begin{array}{c}\text { Agricultural } \\
\text { land }\end{array}$ & 15.60 & 19.88 & 18.22 & 9.60 & 4.28 & -1.66 & -8.63 & -6.00 \\
Pasture land & 5.27 & 3.03 & 1.24 & 0.78 & -2.24 & -1.79 & -0.46 & -4.49 \\
\hline
\end{tabular}


classes have been described in terms of gains and losses. The tendency of changing the land use and land cover from the 1997 to the 2017 were already stated in the form of tabulated and charts as indicated Figure 5 and Table 4. The constructed area increases by $14.1 \mathrm{~km}^{2}$, while agricultural land decreased by 8.63 $\mathrm{km}^{2}$ over a period of 20 years (1997-2017). To know the increment and decrement of the land use land cover in the particular area was determined by using the output of GIS map classification from the period of 1997 to 2017.

\subsection{Cause of Land Use and Land Cover Change Dynamics}

The effect of land use change and impacts were described in Figure 4 and Table 4. Although the times of occurrence of the event are variable, several human and natural factors are the main cause of the land cover land-use dynamics [16]. Although the impact of population growth on the dynamics of land cover is controversial, in other parts of many literatures the rapid growth rate of the population is one of the main causes of population change. According to [17], Rather than negatively impacting the study, he concluded that rapid population growth plays a positive role in the availability of resources. On the contrary, especially in the highlands of Ethiopia, where population pressure is strong, this has led to erosion and degradation of resources [18]. In other parts of many parts of the Ethiopian highlands, the pressures associated with populations have had a negative impact on woodland, pasture, barren soils, riparian vegetation and farmland [19]. This also applies to the city of Debre Tabor, where rapid population growth has resulted in land scarcity, forest cover eradication, soil erosion and land degradation. However, the local community was motivated to practice the afforestation and, consequently, the slow increase in forest cover in urban areas. In addition, the scarcity of land resources forced them to grow agricultural land and pastures.

Therefore, resource become more vulnerable for further erosion and degradation consequently shifted to other land use land cover class.

\subsection{Implication of Land Use and Land Cover Change Dynamics}

The change in land use and the type of land cover need not necessarily lead to soil degradation and erosion. However, as land-use change rapidly spreads and expands rapidly into agricultural areas, pastures and arid areas, fertile soil is more susceptible to massive erosion and degradation, especially for land without dense forest [20] [21]. According to the classified picture of the change found in different land use classes between 1997 and 2017, it was stated that agricultural land, pastures, water bodies and land plantations were transferred to the urbanized area. This suggests that the ways in which land use and land cover classes change over time accelerate erosion and degradation and their associated consequences.

\section{Conclusion}

The rapid expansion of urban areas due to population growth and economic 
growth increases the demand for natural resources and causes changes in land use, especially in urban cities. Therefore, the serious problems associated with rapid development such as additional infrastructure, informal settlements, pollution, destruction of ecological structure and lack of natural resources have been carefully studied with remote sensing and GIS technologies for a fast-growing urban town. This document assesses land use/land cover changes (LULC) in the city of Debre Tabor. The biggest impacts of rapid urbanization and population growth on land cover are changes requiring immediate attention. The categories used for the classification of land use and the change of land cover in the city of Tabor would be built areas, plantations, water bodies, agricultural land and pastures. The results indicate that the city is expanding towards urban expansions. The built area of Debre Tabor, a general increase from 1997 to 2017 would be $14.1 \mathrm{Km}^{2}$, planting- $3.6 \mathrm{Km}^{2}$, and body of water-0.0 $\mathrm{Km}^{2}$, agricultural land $-6 \mathrm{Km}^{2}$ and pasture $-4.49 \mathrm{Km}^{2}$. The total area of bodies of water has been reduced to $0.0 \%$ in a period of twenty years. The increase in the constructed area of the study area would be greater than in the other categories of the city and comprises approximately $52.4 \%$ of the total area of the period from 1997 to 2017.

\section{References}

[1] Erle, E. (2010) Land-Use and Land-Cover Change. In: Pontius, R., Ed., The Encyclopedia of the Earth.

[2] Lambin, E.F., Turner, B.L., Helmut, J.G., Agbola, S.B., Angelsen, A., Bruce, J.W., et al. (2001) The Causes of Land Use and Land Cover Changes: Moving Beyond the Myths. Global Environmental Change, 11, 261-269. https://doi.org/10.1016/S0959-3780(01)00007-3

[3] Campbell, J.B. (1987) Introduction to Remote Sensing. The Guilford, New York.

[4] Lillesand, T.M., Kiefer, R. and Chipman, J. (2004) Remote Sensing and Image Interpretation. 5th Edition, Wiley, New York.

[5] Squires, G.D. (2002) Urban Sprawl and the Uneven Development of Metropolitan America. In: Squires, G.D., Ed., Urban Sprawl: Causes, Consequences, and Policy Responses, Urban Institute Press, Washington DC, 1-22.

[6] Sisay, E., Halefom, A., Khare, D., Singh, L. and Worku, T. (2017) Hydrological Modelling of Ungauged Urban Watershed Using SWAT Model. Modeling Earth Systems and Environment, 3, 693-702. https://doi.org/10.1007/s40808-017-0328-6

[7] Halefom, A., Sisay, E., Khare, D., Singh, L. and Worku, T. (2017) Hydrological Modeling of Urban Catchment Using Semi-Distributed Model. Modeling Earth Systems and Environment, 3, 683-692. https://doi.org/10.1007/s40808-017-0327-7

[8] Fuller, R.A. and Gaston, K.J. (2009) The Scaling of Green Space Coverage in European Cities. Biology Letters, 5, 352-355. https://doi.org/10.1098/rsbl.2009.0010

[9] Birara, H. and Halefom, A. (2017) Evaluation of Seepage Loss in Gorezen Irrigation Canals, Dabat Woreda, North Gondar, Ethiopia. Engineering Science and Technology, an International Journal, 7, 1-9.

[10] Chaudhary, B.S., Saroha, G.P. and Yadav, M. (2008) Human Induced Land Use/Land Cover Changes in Northern Part of Guragon District, Haryana, India. Natural Resources Census Concept. Journal of Human Ecology, 23, 243-252. 
https://doi.org/10.1080/09709274.2008.11906077

[11] Halefom, A. and Sisay, E. (2017) Performance Assessment and Diagnostic Analysis of Minor Irrigation Canal. Engineering Science and Technology, an International Journal, 7, 10-17.

[12] Alberti, M., Weeks, R. and Coe, S. (2004) Urban Land Cover Change Analysis in Central Puget Sound. Photogrammetric Engineering and Remote Sensing, 70, 1043-1052. https://doi.org/10.14358/PERS.70.9.1043

[13] Goetz, S.J., Varlyguin, D., Smith, A.J., Wright, R.K., Prince, S.D. and Mazzacato, M.E. (2004) Application of Multi Temporal Landsat Data to Map and Monitor Land Cover and Land Use Change in the Chesapeake Bay Watershed. In: Smits, P.C. and Bruzzone, L., Eds., Proceedings of the Second International Workshop on the Analysis of Multi Temporal Remote Sensing Images, World Scientific Publishing Co., Singapore. https://doi.org/10.1142/9789812702630_0025

[14] Yang, X. (2002) Satellite Monitoring of Urban Spatial Growth in the Atlanta Metropolitan Area. Photogrammetric Engineering and Remote Sensing, 68, 725-734.

[15] Yuan, F., Sawaya, K.E., Loeffelholz, B.C. and Bauer, M.E. (2005) Land Cover Classification and Change Analysis of the Twin Cities (Minnesota) Metropolitan Area by Multitemporal Landsat Remote Sensing. Remote Sensing of Environment, 98, 317-328. https://doi.org/10.1016/j.rse.2005.08.006

[16] Meyer, W.B. and Turner, II B.L. (1994) Changes in Land Use and Land Cover: A Global Perspective. Vol. 4, Cambridge University Press, Cambridge.

[17] Barbier, E.B. and Burgess, J.C. (1996) Economic Analysis of Deforestation in Mexico. Environment and Development Economics, 1, 203-239.

[18] Grepperud, S. (1996) Population Pressure and Land Degradation: The Case of Ethiopia. Journal of Environmental Economics and Management, 30, 18-33. https://doi.org/10.1006/jeem.1996.0002

[19] Tekle, K. and Hedlund, L. (2000) Land Cover Changes between 1958 and 1986 Kalu District, Southern Wello, Ethiopia. Mountain Research and Development, 20, 42-51. https://doi.org/10.1659/0276-4741(2000)020[0042:LCCBAI]2.0.CO;2

[20] Tegene, B. (2002) Land-Cover/Land-Use Changes in the Derekolli Catchment of the South Welo Zone of Amhara Region, Ethiopia. Eastern Africa Social Science Research Review, 18, 1-20.

[21] Maitima, J.M., Mugatha, S.M., Reid, R.S., Gachimbi, L.N., Majule, A., Lyaruu, H., Pomery, D., Mathai, S. and Mugisha, S. (2009) The Linkages between Land Use Change, Land Degradation and Biodiversity across East Africa. African Journal of Environmental Science and Technology, 3, 310-325. 